\title{
Field Screening of Lentil Genotypes against Aphid Infestation in Inner Tarai of Nepal
}

\author{
Saraswati Neupane ${ }^{1 @}$, Subash Subedi ${ }^{1}$ and Rajendra Darai ${ }^{2}$ \\ ${ }^{1}$ Nepal Agricultural Research Council, National Maize Research Program, Rampur, Chitwan, Nepal; @: \\ sarusanu2017@gmail.com, ORCID: https://orcid.org/0000-0003-3033-5840; SS: subedi.subash1@gmail.com \\ ${ }^{2}$ Nepal Agricultural Research Council, Grain Legumes Research Program, Khajura, Banke, Nepal; RD: \\ rajendra5042@yahoo.co.uk
}

Received 22 Sept 2019, Revised 09 Dec 2019, Accepted 15 Feb 2020, Published 17 March 2020

Scientific Editors: Jiban Shrestha, Resham Bahadur Thapa, Manoj Thakur

Copyright (C) 2020 NARC. Permits unrestricted use, distribution and

reproduction in any medium provided the original work is properly cited.

The authors declare that there is no conflict of interest.

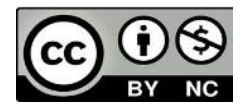

OPEN ACCESS

icensed under the Creative Commons Attribution NonCommercial 4.0 International (CC BY-NC 4.0)

\section{ABSTRACT}

Twenty lentil (Lens culinaris Medik) genotypes received from Grain Legumes Research Program, Khajura, Banke were screened for relative tolerance against aphid (Aphis craccivora Koch.) at the research field of National Maize Research Program, Rampur, Chitwan during winter seasons of two consecutive years 2016 and 2017. The design of the experiment was Randomized Complete Block having three replications. The unit plot size was $4 \mathrm{~m} \times 1 \mathrm{~m}$ with $25 \mathrm{~cm}$ row to row spacing and continue plant to plant spacing was maintained and net harvested plot was 4 square meters. The recommended dose of fertilizer was $20: 40: 20 \mathrm{~N}: \mathrm{P}_{2} \mathrm{O}_{5}: \mathrm{K}_{2} \mathrm{O} \mathrm{kg} / \mathrm{ha}$ and seed rate $30 \mathrm{~kg} / \mathrm{ha}$. Insect data were collected based on aphid population found at apical twigs $(10 \mathrm{~cm})$ per plant and scoring was done during flowering and pod formation stage. The grain yield was recorded. All screened genotypes differed significantly $(\mathrm{p}<0.05)$ on aphid population and grain yield. Genotypes, ILL 9924, RL 83, ILL 10856, ILL 6458 and RL 67 were less susceptible with higher grain yield. These results have important implications for the development of aphid tolerant high yielding lentil variety in inner Tarai of Nepal.

Keywords: Aphis craccivora, damage, host tolerance, lentil

सारांश

लाही किरा कम लाग्ने तथा यसको आक्रमण सहन सक्ने जातहरुको छनोट तथा बिकासको लागि कोसेबाली अनुसन्धान कार्यक्रम, खजुरा, बाँके बाट प्राप्त २० वटा मसुरोको जातहरुलाई लगातार सन् २०१६ र २०१७ को हिउदमा राष्ट्रिय मकैबालि अनुसन्धान कार्यक्रम, रामपर, चितवनको अनुसन्धान ब्लकमा लगाई परिक्षणहरु संचालन गरिएको थियो। परिक्षणहरुलाई पूर्ण रेन्ड़ोमाइज्ड ब्लक ढांचामा तिन पटक ब्यबस्थित गरिएको थियो। प्रत्येक मसरोको जातहरुलाइ चार बर्ग मिटरको प्लटहरुमा, एक लाइन देखि अर्को लाइन बिचको दुरी २५ से.मि. तथा बिरुवा देखि बिरुवा बीचको दुरी लगातार कायम हुने गरि लगाइएको थियो। मलखादको मात्रा २०:४०:२० नाइट्रोजन : फस्फोरस : पोटाश के.जी./हे. तथा बिउ दर ३० के.जी./हे. कायम गरिएको थियो । मसुरोको फल फल्ले र कोशा लाग्ने अबस्थामा प्रत्येक बिरुवाको टुप्पोमा दस से.मि. सम्म लाही किराको संख्या मापन साथै उत्पादन आंकडा पनि रेकर्ड गरिएको थियो। लाही किराको संख्या, क्षतीको मापन साथै अन्य उत्पादन सम्बन्धि आंकडाहरुको विश्लेषण गर्दा, आइ.एल.एल. ९९२४, आर.एल.५३, आइ.एल.एल.१०६४६, आइ.एल.एल.७४५६ र आर.एल.६७ जातहरु लाही किराको आक्रमण सहन सक्ने, क्षती कम हुने साथै उच्च उत्पादन दिने मसरोको जातहरुको रुपमा पाइयो। यस परिक्षण बाट प्राप्त नतिजाहरु, नेपालको भित्रि मधेश क्षेत्रमा लाही किराको आक्रमण सहन सक्ने साथै उच्च उत्पादन दिने मसुरो जातहरुको रुपमा बिकाश गर्नको लागि उपयोगी हुनेछ।

\section{INTRODUCTION}

Lentil (Lens culinaris Medik) is one of the most important cool seasons, annual grain legume or "pulse crop" that is considered a cousin of the bean. It is a self-pollinated, diploid $(2 n=14)$, which belongs to the family leguminosae and subfamily papilionoidae. The major lentil growing countries in South Asia are India, Nepal, Bangladesh and Pakistan. It is highly commercialized pulse crops among the grain legumes in terms of area (206969 ha), production (254308t) and productivity (1229 kg/ha), which shares almost $62 \%$ of total area and $65 \%$ of total production of pulses and also rates the higher 
consumer preference in Nepal (MoALD 2017). In Nepal, there are unique and nutrition rich lentil landraces (Joshi et al 2019), but the productivity of lentil is low, one of the major regions for low productivity is significant damage caused by various insect pests. About three dozen insect pests have been reported to infest lentil under field and storage condition (Hariri and Tahhan 1983) out of which 21 species have been reported in India and South Asian region (Lal 1992). However, only some of these are economically important and require control measures. The field insect pests include aphids, cutworms, thrips, bud weevil, pod borer and in storage, species of seed beetles Bruchus and Callosobruchus spp. can cause severe damage in lentil (GLRP 2012). Among the insects, aphid is most serious, damaging and emerging pests for lentil crop. Sometimes it can cause total failure of production and damages the crop direct through by sucking cell sap. Aphids are able to multiply quickly that a moderate infestation can become a damaging population in less than a week (GLRP 2014). Aphids damage the lentil mostly by sucking sap but are also responsible for the transmission of viruses. Aphids heavily fed plants upon are stunted and produce fewer and smaller pods and seeds. Smaller plants may die from aphid through cell sap sucking. Aphids can destroy about $25-50 \%$ of developing plants (Kishor et al 2019). The cultivation of resistant genotypes is considered as simple, easy, cheap and ideal method of combating pest problem without causing any hazards to environment and development of resistance in insect pest. From farmer's point of view, this can be a most acceptable form of pest control technique. Selection of resistant genotypes may be helpful in reducing pest damage. Therefore, the present study was designed to screen different genotypes of lentil against the infestation of Aphis craccivora Koch in inner Tarai of Nepal. The present study was undertaken in order to find out the tolerant lentil genotypes among different traits and the direct and indirect contributions of these traits toward yield.

\section{MATERIALS AND METHODS}

Twenty lentil genotypes received from Grain Legumes Research Program, Khajura, Banke were screened for relative tolerance against aphid at the research field of National Maize Research Program (NMRP), Rampur, Chitwan during winter seasons of two consecutive years 2016 and 2017. The geographical location of NMRP, Rampur, Chitwan is in $27^{\circ} 40^{\prime} \mathrm{N}$ latitude, $84^{\circ} 19^{\prime} \mathrm{E}$ longitude at an altitude of 228 meter above sea level. It has humid and subtropical climate with cool winter and hot summer. The soil is generally acidic ( $\mathrm{pH} 4.6-5.7)$, light textured and sandy loam. The average total annual rainfall was $2215.30 \mathrm{~mm}$ with a distinct monsoon period (>75\% of annual rainfall) from midJune to mid-September. The design of the experiment was Randomized Complete Block having three replications. The unit plot size was $4 \mathrm{~m} \times 1 \mathrm{~m}$ with $25 \mathrm{~cm}$ row to row spacing and continues plant to plant spacing was maintained and net harvested plot was 4 square meters. The recommended dose of fertilizer was 20:40:20 N: $\mathrm{P}_{2} \mathrm{O}_{5}: \mathrm{K}_{2} \mathrm{O} \mathrm{kg} / \mathrm{ha}$ and seed rate $30 \mathrm{~kg} / \mathrm{ha}$. Insect data were collected based on aphid population found at apical twigs $(10 \mathrm{~cm})$ per plant and aphid scoring during flowering and pod formation stage. From each entry, randomly ten plants were selected and recorded the observations. The assessment of infestation by insect pests on various crops was done as per the scale given by Nagrare and his co-workers (Nagrare et al 2011). The grain yield was recorded. All data were analyzed statistically using MSTAT-C computer package program. The treatment means were compared by the Least Significant Difference (LSD) test at 5\% level (Gomez and Gomez 1984, Shrestha, 2019). The aphid population data were subjected to square root transformation before statistical analysis.

\section{RESULTS}

The results revealed that all the lentil genotypes differed significantly in respect the aphid population per plant apical twigs $(10 \mathrm{~cm}$ ) during flowering and pod formation stage at NMRP, Rampur in 2016 winter season. Among the genotypes, ILL 6458 ( 2 aphid /plant) was recorded as the least susceptible genotype followed by Sagun (2 aphid /plant), ILL-10856 (3 aphid/plant), RL-83 (4 aphid /plant), ILL-9924 (5 aphid /plant) and RL-67 (6 aphid/plant) respectively (Table 1). Statistically highly significant differences were observed in grain yield of different lentil genotypes. The higher grain yield was found in genotype ILL 9924 (1727 kg/ha), followed by RL-83 (1632 kg/ha) and ILL 10856 (1570 kg/ha) (Table 1). 
Table 1. Response of different lentil genotypes against the aphid infestation and grain yield at NMRP, Rampur during 2016 winter

\begin{tabular}{|c|c|c|c|c|c|}
\hline \multirow[t]{2}{*}{ Genotypes } & \multicolumn{2}{|c|}{ Aphid / plant apical twigs $(10 \mathrm{~cm})$} & \multirow{2}{*}{$\begin{array}{l}\text { Mean aphid } \\
\text { population/plant }\end{array}$} & \multirow{2}{*}{$\begin{array}{l}\text { Aphid Scoring } \\
(1-4)\end{array}$} & \multirow{2}{*}{$\begin{array}{l}\text { Grain Yield } \\
\text { (kg/ha) }\end{array}$} \\
\hline & $\begin{array}{l}\text { During } \\
\text { flowering }\end{array}$ & $\begin{array}{l}\text { During pod } \\
\text { formation }\end{array}$ & & & \\
\hline RL-68 & $\begin{array}{l}\dagger 29 \\
(5.43)\end{array}$ & $\begin{array}{l}59 \\
(7.71)\end{array}$ & $\begin{array}{l}44 \\
(6.67)\end{array}$ & 3 & 1129 \\
\hline RL-67 & $\begin{array}{l}0 \\
(0.71)\end{array}$ & $\begin{array}{l}11 \\
(3.43)\end{array}$ & $\begin{array}{l}6 \\
(2.48)\end{array}$ & 1 & 1505 \\
\hline RL-71 & $\begin{array}{l}0 \\
(0.71)\end{array}$ & $\begin{array}{l}21 \\
(4.64)\end{array}$ & $\begin{array}{l}11 \\
(3.31)\end{array}$ & 1 & 1435 \\
\hline RL-45 & $\begin{array}{l}0 \\
(0.71)\end{array}$ & $\begin{array}{l}24 \\
(4.91)\end{array}$ & $\begin{array}{l}12 \\
(3.51)\end{array}$ & 1 & 1410 \\
\hline RL-83 & $\begin{array}{l}0 \\
(0.71)\end{array}$ & $\begin{array}{l}7 \\
(2.74)\end{array}$ & $\begin{array}{l}4 \\
(1.99)\end{array}$ & 1 & 1632 \\
\hline RL-28 & $\begin{array}{l}20 \\
(4.53)\end{array}$ & $\begin{array}{l}50 \\
(7.11)\end{array}$ & $\begin{array}{l}35 \\
(5.96)\end{array}$ & 3 & 1197 \\
\hline ILL-6458 & $\begin{array}{l}0 \\
(0.71)\end{array}$ & $\begin{array}{l}3 \\
(1.81)\end{array}$ & $\begin{array}{l}2 \\
(1.38)\end{array}$ & 1 & 1535 \\
\hline ILL-9924 & $\begin{array}{l}0 \\
(0.71)\end{array}$ & $\begin{array}{l}10 \\
(3.24)\end{array}$ & $\begin{array}{l}5 \\
(2.35)\end{array}$ & 1 & 1727 \\
\hline NR2001-71-3 & $\begin{array}{l}25 \\
(5.05)\end{array}$ & $\begin{array}{l}55 \\
(7.45)\end{array}$ & $\begin{array}{l}40 \\
(6.36)\end{array}$ & 3 & 1170 \\
\hline RL-44 & $\begin{array}{l}36 \\
(6.04)\end{array}$ & $\begin{array}{l}66 \\
(8.15)\end{array}$ & $\begin{array}{l}51 \\
(7.18)\end{array}$ & 3 & 1070 \\
\hline ILL-10068 & $\begin{array}{l}0 \\
(0.71)\end{array}$ & $\begin{array}{l}15 \\
(3.94)\end{array}$ & $\begin{array}{l}8 \\
(2.83)\end{array}$ & 2 & 1440 \\
\hline ILL-10853 & $\begin{array}{l}8 \\
(2.91)\end{array}$ & $\begin{array}{l}38 \\
(6.20)\end{array}$ & $\begin{array}{l}23 \\
(4.85)\end{array}$ & 2 & 1294 \\
\hline ILL-2437 & $\begin{array}{l}17 \\
(4.18)\end{array}$ & $\begin{array}{l}47 \\
(6.89)\end{array}$ & $\begin{array}{l}32 \\
(5.70)\end{array}$ & 2 & 1252 \\
\hline ILL-10045 & $\begin{array}{l}14 \\
(3.76)\end{array}$ & $\begin{array}{l}44 \\
(6.65)\end{array}$ & $\begin{array}{l}29 \\
(5.40)\end{array}$ & 2 & 1259 \\
\hline ILL-10065 & $\begin{array}{l}38 \\
(6.20)\end{array}$ & $\begin{array}{l}68 \\
(8.28)\end{array}$ & $\begin{array}{l}53 \\
(7.31)\end{array}$ & 3 & 962 \\
\hline RL-60 & $\begin{array}{l}33 \\
(5.82)\end{array}$ & $\begin{array}{l}63 \\
(7.99)\end{array}$ & $\begin{array}{l}48 \\
(6.99)\end{array}$ & 3 & 1087 \\
\hline ILL-8010 & $\begin{array}{l}31 \\
(5.61)\end{array}$ & $\begin{array}{l}61 \\
(7.84)\end{array}$ & $\begin{array}{l}46 \\
(6.82)\end{array}$ & 3 & 1099 \\
\hline ILL-10856 & $\begin{array}{l}0 \\
(0.71)\end{array}$ & $\begin{array}{l}5 \\
(2.34)\end{array}$ & $\begin{array}{l}3 \\
(1.73)\end{array}$ & 1 & 1570 \\
\hline RL-55 & $\begin{array}{l}0.7 \\
(1.0)\end{array}$ & $\begin{array}{l}30 \\
(5.52)\end{array}$ & $\begin{array}{l}15 \\
(3.98)\end{array}$ & 2 & 1339 \\
\hline Sagun & $\begin{array}{l}0 \\
(0.71)\end{array}$ & $\begin{array}{l}4 \\
(2.04)\end{array}$ & $\begin{array}{l}2 \\
(1.52)\end{array}$ & 1 & 1510 \\
\hline $\mathrm{P}$ value & 0.000 & 0.000 & 0.000 & 0.000 & 0.000 \\
\hline LSD (0.05) & 0.22 & 0.32 & 0.23 & 0.38 & 118.7 \\
\hline $\mathrm{CV}, \%$ & 4.64 & 3.57 & 3.18 & 11.77 & 5.39 \\
\hline
\end{tabular}

${ }^{\dagger}$ Means of 3 replications, RL-Rampur Lentil, ILL-ICARDA Lentil Line, cm- centimeter, $\mathrm{kg} / \mathrm{ha}$ - kilogram per hectare

During 2017 winter, all the screened lentil genotypes differed significantly with aphid population per plant apical twigs $(10 \mathrm{~cm})$ during flowering and pod formation stage at NMRP, Rampur. Among the genotypes, ILL 9924 ( 2 aphid /plant) was recorded as the least susceptible genotype followed by RL83 (3 aphid /plant), ILL-10856 (4 aphid /plant), ILL 6458 (6 aphid /plant) and Sagun (8 aphid/plant) respectively (Table 2 ). 
Table 2. Evaluation of lentil genotypes against the aphid infestation and grain yield at NMRP, Rampur during 2017 winter

\begin{tabular}{|c|c|c|c|c|c|}
\hline \multirow[t]{2}{*}{ Genotypes } & \multicolumn{2}{|c|}{ Aphid /plant apical twigs $(10 \mathrm{~cm})$} & \multirow{2}{*}{$\begin{array}{l}\text { Mean aphid } \\
\text { population/ } \\
\text { plant }\end{array}$} & \multirow{2}{*}{$\begin{array}{l}\text { Aphid } \\
\text { Scoring } \\
(1-4)\end{array}$} & \multirow{2}{*}{$\begin{array}{l}\text { Grain } \\
\text { Yield } \\
\text { (kg/ha) }\end{array}$} \\
\hline & $\begin{array}{l}\text { During } \\
\text { flowering }\end{array}$ & $\begin{array}{l}\text { During pod } \\
\text { formation }\end{array}$ & & & \\
\hline RL-68 & $\begin{array}{l}+46 \\
(6.82)\end{array}$ & $\begin{array}{l}72 \\
(8.51)\end{array}$ & $\begin{array}{l}59 \\
(7.67)\end{array}$ & 3 & 1087 \\
\hline RL-67 & $\begin{array}{l}0 \\
(0.71)\end{array}$ & $\begin{array}{l}24 \\
(4.98)\end{array}$ & $\begin{array}{l}12 \\
(2.93)\end{array}$ & 1 & 1463 \\
\hline RL-71 & $\begin{array}{l}8 \\
(2.90)\end{array}$ & $\begin{array}{l}34 \\
(5.87)\end{array}$ & $\begin{array}{l}21 \\
(4.39)\end{array}$ & 2 & 1393 \\
\hline RL-45 & $\begin{array}{l}11 \\
(3.34)\end{array}$ & $\begin{array}{l}37 \\
(6.09)\end{array}$ & $\begin{array}{l}24 \\
(4.72)\end{array}$ & 2 & 1368 \\
\hline RL-83 & $\begin{array}{l}0 \\
(0.71)\end{array}$ & $\begin{array}{l}6 \\
(2.55)\end{array}$ & $\begin{array}{l}3 \\
(1.63)\end{array}$ & 1 & 1590 \\
\hline RL-28 & $\begin{array}{l}37 \\
(6.12)\end{array}$ & $\begin{array}{l}63 \\
(7.97)\end{array}$ & $\begin{array}{l}50 \\
(7.05)\end{array}$ & 3 & 1155 \\
\hline ILL-6458 & $\begin{array}{l}0 \\
(0.71)\end{array}$ & $\begin{array}{l}12 \\
(3.53)\end{array}$ & $\begin{array}{l}6 \\
(2.12)\end{array}$ & 1 & 1493 \\
\hline ILL-9924 & $\begin{array}{l}0 \\
(0.71)\end{array}$ & $\begin{array}{l}3 \\
(1.86)\end{array}$ & $\begin{array}{l}2 \\
(1.28)\end{array}$ & 1 & 1685 \\
\hline NR2001-71-3 & $\begin{array}{l}42 \\
(6.52)\end{array}$ & $\begin{array}{l}68 \\
(8.28)\end{array}$ & $\begin{array}{l}55 \\
(7.40)\end{array}$ & 3 & 1128 \\
\hline RL-44 & $\begin{array}{l}53 \\
(7.31)\end{array}$ & $\begin{array}{l}79 \\
(8.92)\end{array}$ & $\begin{array}{l}66 \\
(8.12)\end{array}$ & 4 & 1028 \\
\hline ILL-10068 & $\begin{array}{l}2 \\
(1.56)\end{array}$ & $\begin{array}{l}28 \\
(5.34)\end{array}$ & $\begin{array}{l}15 \\
(3.45)\end{array}$ & 2 & 1398 \\
\hline ILL-10853 & $\begin{array}{l}25 \\
(5.05)\end{array}$ & $\begin{array}{l}51 \\
(7.18)\end{array}$ & $\begin{array}{l}38 \\
(6.11)\end{array}$ & 3 & 1252 \\
\hline ILL-2437 & $\begin{array}{l}34 \\
(5.87)\end{array}$ & $\begin{array}{l}60 \\
(7.78)\end{array}$ & $\begin{array}{l}47 \\
(6.83)\end{array}$ & 3 & 1210 \\
\hline ILL-10045 & $\begin{array}{l}30 \\
(5.58)\end{array}$ & $\begin{array}{l}57 \\
(7.56)\end{array}$ & $\begin{array}{l}44 \\
(6.57)\end{array}$ & 3 & 1217 \\
\hline ILL-10065 & $\begin{array}{l}55 \\
(7.45)\end{array}$ & $\begin{array}{l}81 \\
(9.03)\end{array}$ & $\begin{array}{l}68 \\
(8.24)\end{array}$ & 4 & 920 \\
\hline RL-60 & $\begin{array}{l}50 \\
(7.13)\end{array}$ & $\begin{array}{l}76 \\
(8.77)\end{array}$ & $\begin{array}{l}63 \\
(7.95)\end{array}$ & 4 & 1045 \\
\hline ILL-8010 & $\begin{array}{l}48 \\
(6.96)\end{array}$ & $\begin{array}{l}74 \\
(8.63)\end{array}$ & $\begin{array}{l}61 \\
(7.80)\end{array}$ & 3 & 1057 \\
\hline ILL-10856 & $\begin{array}{l}0 \\
(0.71)\end{array}$ & $\begin{array}{l}8 \\
(2.91)\end{array}$ & $\begin{array}{l}4 \\
(1.81)\end{array}$ & 1 & 1528 \\
\hline RL-55 & $\begin{array}{l}17 \\
(4.18)\end{array}$ & $\begin{array}{l}43 \\
(6.60)\end{array}$ & $\begin{array}{l}30 \\
(5.39)\end{array}$ & 1 & 1297 \\
\hline Sagun & $\begin{array}{l}0 \\
(0.71)\end{array}$ & $\begin{array}{l}16 \\
(4.06)\end{array}$ & $\begin{array}{l}8 \\
(2.38)\end{array}$ & 2 & 1468 \\
\hline $\mathrm{P}$ value & 0.000 & 0.000 & 0.000 & 0.000 & 0.000 \\
\hline LSD (0.05) & 0.24 & 0.18 & 0.18 & 0.38 & 115.70 \\
\hline $\mathrm{CV}, \%$ & 3.57 & 1.74 & 2.12 & 9.75 & 4.57 \\
\hline
\end{tabular}

${ }^{\dagger}$ Means of 3 replications, RL- Rampur Lentil, ILL- ICARDA Lentil Line, cm- centimeter, kg/ha- kilogram per hectare

The higher grain yield (Table 2) was found in genotypes ILL 9924 (1685 kg/ha), followed by RL-83 (1590 kg/ha) and ILL 10856 (1528 kg/ha) and ILL 6458 (1493 kg/ha).

Relationship between grain yield and aphid population

The predicted linear regression line was displayed downward slope, ie $\mathrm{Y}=-9.584 \mathrm{x}+1585$, with regression coefficient $\mathrm{R}^{2}=0.95$, where ' $\mathrm{Y}$ ' denoted predicted grain yield of crop and ' $\mathrm{x}$ ' stood for mean aphid population per plant. The estimated regression line indicated that the unit rise in the aphid population, there existed possibilities of grain yield reduction by $9.584 \mathrm{~kg} / \mathrm{ha}$ (Figure 1). 


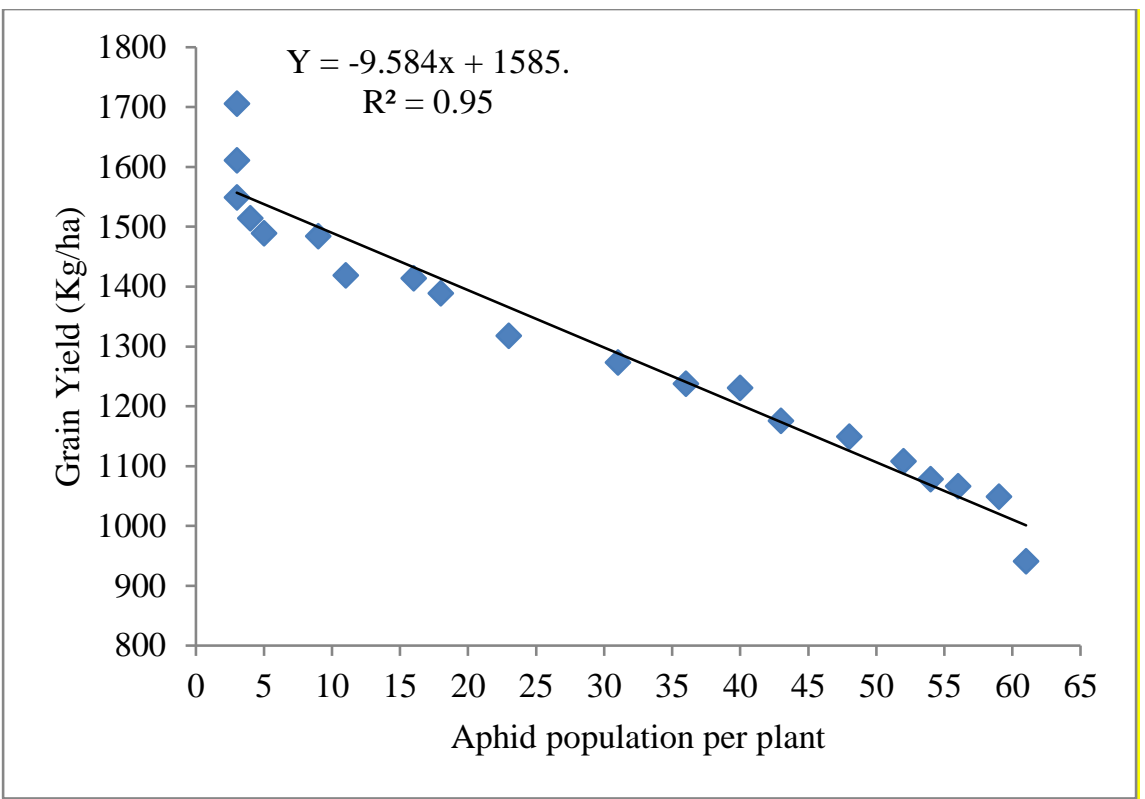

Figure 1. Relationship between grain yield and mean aphid population per plant during winter season 2017 at NMRP, Rampur, Nepal.

\section{DISCUSSION}

The mechanism of host plant resistance in response to insect infestation consists of a series of biochemical events, including increased production of phenolics, mediated by phenylalanine ammonia-lyase, tyrosine ammonialyase, peroxidase and polyphenol oxidase (Divya et al 2017). The primary metabolites include carbohydrates and proteins, which are exploited by the herbivores for their growth and development and also function as precursors of secondary substances, which are major elements of resistance in plants (Edreva et al 2008). The present finding was supported by the reports of the Kishor et al (2019) who screened one hundred and twelve accessions of lentil for tolerance to black aphids and some morphological attributes were recorded to find the association with aphid incidence. Low infestation of aphids was observed on genotypes with green or yellowish green foliage and slightly pubescent leaves and yield attributes were recorded to find the association with aphid incidence (Kumari et al 2009). Moderate infestation was recorded in genotypes with dark green foliage while genotypes with ash green foliage and densely pubescent leaves were highly susceptible to aphids (Morales and Bleicher 2007).

\section{CONCLUSION}

Grain yield had strong negative correlation with the aphid population. Lentil genotypes ILL 9924, RL 83, ILL 10856, ILL 6458 and RL 67 were less susceptible to aphid infestation and resulted in higher grain yield. The study can be useful for selecting suitable lentil genotypes for the development of aphid tolerant high yielding lentil variety in inner Tarai of Nepal.

\section{ACKNOWLEDGEMENTS}

The fund for this study was achieved from NARC. Acknowledgements go to both NMRP and GLRP team and other technical staffs of NARC for their valuable suggestions, continuous support and facilities during experimentation period.

\section{REFERENCES}

Divya TC, IS Katageri, MP Jadhav, S Adiger, HM Vamadevaiah and NS Olekar. 2017. Biochemical constituents imparting resistance to sucking pest aphid in cotton (Gossypium spp.). International Journal of Current Microbiology and Applied Sciences 6(12): 2749-2757.

Edreva A, V Velikova, T Tsonev, S Dagnon, A Gürel, L Aktaş and E Gesheva. 2008. Stress-protective role of secondary metabolites: diversity of functions and mechanisms. General and Applied Plant Physiology 34(1-2):67-78. 
GLRP. 2012. Annual Report 2068/69 (2011/12). Grain Legumes Research Program, NARC, Rampur, Chitwan, Nepal.

GLRP. 2014. Annual Report 2070/71 (2013/14). Grain Legumes Research Program, NARC, Rampur, Chitwan, Nepal.

Gomez KA and AA Gomez. 1984. Statistical procedures for agricultural research. New York: Wiley.

Hariri $\mathrm{G}$ and $\mathrm{O}$ Tahhan. 1983. Updating results on evaluation of the major insects which infest faba bean, lentil and chickpea in Syria. Arab Journal of Plant Protection 1(1):13-21.

Joshi BK, R Shrestha, IP Gautam, AP Poudel and TP Gotame. 2019. Neglected and Underutilized Species (NUS), and Future Smart Food (FSF) in Nepal. National Agriculture Genetic Resources Center (NAGRC, National Genebank), NARC, Khumaltar, Kathmandu, Nepal.

Kishor DR, R Prasad, S Moses and PP Singh. 2019. Population dynamics of aphid and pod borer on lentil and their natural enemies during rabi Season 2017 at Pusa, Samastipur. Current Journal of Applied Science and Technology 32(2): 1-6.

Kumari J, R Ahmad, S Chandra and GK Jha. 2009. Determination of morpholological attributes imparting resistance against aphids (Aphis craccivora Koch) in lentil (Lens culinaris Medik). Archives of Phytopathology and Plant Protection 42(1): 52-57.

Lal SS. 1992. Insect pests of lentil and their management. Agricultural Review 13: 225-232.

MoALD. 2017. Statistical information on Nepalese Agriculture 2016/17. Agri-Business Promotion and Statistics Division, Ministry of Agriculture and Livestock Development, Kathmandu, Nepal.

Morales JGL and E Bleicher. 2007. Black aphid, Aphis craccivora Koch, preference to different cowpea, Vigna unguiculata (L.) Walp. cultivars. Ciencia-Rural 37(6): 1554-1557.

Nagrare VS, S Kranthi, R Kumar, B Dharajothi, M Amutha, AJ Deshmukh, KD Bisane and KR Kranthi. 2011. Compendium of cotton mealybugs. Technical Bulletin, Central Institute for Cotton Research, Nagpur, India.

Shrestha J. 2019. P-Value: A true test of significance in agricultural research. https://www.linkedin.com/pulse/pvalue-test-significance-agricultural-research-jiban-shrestha/. 